\title{
The effects of critical thinking instruction through asynchronous learning tools on writing
}

\author{
1Sibel Aygün, 2Fatih Yavuz* \\ ${ }^{1}$ School of Foreign Languages, Yalova University, Turkey \\ ${ }^{2}$ Department of Foreign Language Education, Faculty of Education, Balıkesir University, \\ Turkey
}

*Corresponding Author

Email: yavuzf@balikesir.edu.tr

\begin{abstract}
In writing classes, besides mastering the language items and writing rhetoric, students are required to use some high order thinking skills to be able to write academically. Hence, this study basically aims to see the effectiveness of the use of critical thinking skills on writing achievements of the Turkish EFL students. The purpose of the study is to see if online critical thinking treatment affects students' use of critical thinking skills in their writings. In addition, students' attitudes towards asynchronous learning tools during the study were observed. At the beginning and end of the study, 16 students in control group and 16 students in experimental group answered the questions in the critical thinking disposition scale. In addition to this, their writing performances were evaluated before and after the study. Meanwhile, experimental group students were exposed to 8-week online critical thinking treatment. The data gathered were statistically analysed and the results indicate that while the students' writing performances do not differ significantly before and after the online critical thinking treatment, it has significantly contributed to the students' use of critical thinking skills while writing.
\end{abstract}

Keywords: English as a Foreign Language; Writing Skill; Critical Thinking, Asynchronous Learning Tools

$\begin{array}{llll}\text { Received: } & \text { Revised: } & \text { Accepted: } & \text { Published: } \\ \text { 15 April 2020 } & \text { 6 July 2020 } & \text { 7 August 2020 } & 31 \text { August 2020 }\end{array}$

\section{INTRODUCTION}

The main purpose of learning a language is to communicate and for communication in that language, learners need to master all four skills, which are listening, reading, writing and speaking. Language learning, no matter it is a second or foreign for the learner, is a long and challenging path requiring the learners to progress consistently by adding new experiences in each skill to the old ones so that they can associate and internalize what they have acquired in the target language. In this demanding pathway, learners do not have the priority of preferring just one or two skills to master and leaving the others aside. In order to be able to comprehend the message, they primarily need listening and reading skills, which are named as receptive skills. For responding and self-expression, they are to develop speaking and writing 
Aygün, S. \& Yavuz, F. (2020). The effects of critical thinking instruction through asynchronous learning tools on writing. EduLite: Journal of English Education, Literature, and Culture, 5 (2), 176-191. DOI: http://dx.doi.org/10.30659/e.5.2.176-191

skills, called as productive skills. Namely, they build the language on those receptive and productive skills. Moreover, it is clear that each of these skills is equally important being a prerequisite of one another and developing interrelatedly. However, many language learners find productive skills overwhelming since they push students to do something more than keeping quiet and taking in what they are exposed to in the target language. They do not struggle enough for these two skills, which are speaking and writing since they need to produce for the development of them; and producing, or creating, is another skill which needs constant and special training and practice as well. In order to learn how to produce in another language, developing thinking skills is a must. Developing high order thinking skills alongside the target language is what learners need the most to be able to manage the challenge of mastering productive skills. Consequently, it can be said that there must be a close relationship between writing instruction and critical thinking development. With the help of developing technology, it seems possible and feasible to maintain that relationship between these two skills. By utilizing learning management systems, the implementation of critical thinking instruction in writing courses is likely to contribute to the development of writing skill since students will be engaging not only in technology but also in thinking activities outside the classroom at times that they feel ready to participate. Thus, educators can focus on developing students' critical thinking abilities, which will possibly reflect to their writing abilities in turn when the relation between critical thinking and writing is taken into consideration. When all these parameters are taken into consideration, this experimental study aims to answer the following questions: 1) What are B2 level Turkish EFL students' critical thinking attitudes? 2)What are the attitudes of B2 level Turkish EFL students towards asynchronous learning tools? 3) Are there any effects ofengaging in critical thinking activities via asynchronous learning tools on the use of students' critical thinking skills in their writing tasks? If yes, how does it affect? 4) How does engaging in critical thinking activities via asynchronous learning tools affect students' writing achievements?

\section{Critical thinking and ELT}

Critical thinking is a concept that is highly difficult to identify and agree on since it is applicable to every aspect of life and is one of the significant requirements of this information age. Thus, in some studies, researchers tried to find a common definition and generalized explanation for it and conducted their studies on people with different backgrounds and perspectives. For example, Moore (2013) investigated ideas of academics from history, philosophy and cultural studies to see how they define critical thinking; and found out that critical thinking is identified as judgment, as skepticism, as a simple originality, as sensitive readings, as rationality, as an activist engagement with knowledge and as a self-reflexivity. Another study to define what critical thinking is; what comprises it, and how it is assessed was conducted on a larger scale on the demand of American Philosophical Association between 1988 and 1989. At the end of long discussions and studies, the experts in that study announced that they understand critical thinking to be purposeful, self-regulatory judgment which results in 
interpretation, analysis, evaluation, and inference as well as explanation of the evidential conceptual, methodological, criteriological, or contextual considerations upon which that judgment is based.' in the Delphi Report.Some other researchers are interested in the matter of teaching critical thinking and have searched to find if schools teach critical thinking and improve students' critical thinking skill; and if so, how? With a meta-analysis to synthesize research on gains in critical thinking skills and attitudinal dispositions over various time frames in college, Huber and Kuncel (2016) resulted in that both critical thinking skills and dispositions show progress substantially over a standard college experience. From another perspective, Plotnikova and Strukov (2019) concluded that critical thinking skills were essential for higher education students and training students in teams helps the formation of critical thinking skills for these students.

How to define critical thinking and the skills that are related to critical thinking in ELT concept has become one of the main research questions as well. For example, Marin and Pava (2017) aimed to shed light on some conceptions that university English teachers had in mind about critical thinking and to understandthe relation between EFL and these conceptions. They conducted their study on ten English teachers from five universities in Colombia to conclude that critical thinking in EFL meant students who were competent in communication, creative, argumentative, decision makers and problem solvers. They also need to be autonomous learners with metacognitive abilities and emotions.On a larger scale, in their article, Shaila and Trudell (2010) described how a group of teachers turned a traditional curriculum into one that would equip students with critical thinking abilities, and what the new curriculum brought about from the teachers' and students' perspectives. They reported that the students in that pre-university program with the new curriculum stated they readily adapted to the critical thinking, enhancement and writing classes; and the teachers were amazed at the progress even the shiest student showed after the curricular change.

Now that the effects of critical thinking on language learning are obvious, whether the teachers of English are aware of the importance of it and the ways to apply and develop it in language classes has become another important topic to study on. Among the related studies, one was in Palestine. Jabr (2003) aimed to examine teachers' perception about teaching critical thinking skills in Palestinian schools. Employing different data collection tools such as a questionnaire, interviews, classroom observations; he found that the teachers in Palestinian schools are not successful or persistent in teaching critical thinking skills. The study also revealed that English language teachers believed that they provided the students with the necessities of critical thinking activities, yet they were not able to teach those skills as they assumed. As to how to integrate critical thinking into language classes, there are various methods studied and one of them was by Jensen in 2015. Jenson focused on Socratic Method in critical thinking and designed his study accordingly. He focused on seventh grade students in Nebraska and observed the critical thinking skills teaching environments. He cooperated with two language teachers who were competent in recognizing critical thinking skills, the Socratic Method, Socratic Questioning, Socratic Seminars and the Holistic 
Aygün, S. \& Yavuz, F. (2020). The effects of critical thinking instruction through asynchronous learning tools on writing. EduLite: Journal of English Education, Literature, and Culture, 5 (2), 176-191. DOI: http://dx.doi.org/10.30659/e.5.2.176-191

Rubric. They integrated Socratic Questioning in their classes for five weeks and concluded that thanks to Socratic Method, the students succeeded in improving their critical thinking skills.

\section{Critical thinking and writing skill}

Many studies have focused on the relationship between critical thinking and writing skills in language learning; however, some of them specifically emphasized the effects of critical thinking on the development of writing skill whereas some others concentrated on the effects of writing skill on the development of critical thinking skill. One example of the former ones is Golpour's study in 2014. He studied with Iranian EFL students to see the effects of critical thinking skills of the students on their writing performances. Golpour found that the students with high critical thinking levels wrote better descriptive and argumentative writing pieces than the ones with low levels of critical thinking skills. In order to see the results of his study on 64 advanced level EFL learners, he used the Longman paper and pencil test, a critical thinking questionnaire, an analytic scale of Weir. Another example is the study carried out by Dong and Yue in 2015. Their purpose was to explore the relation between writing proficiency and critical thinking skills of college students; and to introduce the criterion of critical thinking skill into the college English writing rubric. In the study, 30 writing samples from students on 15 different topics were analyzed according to the critical thinking hierarchy theory model proposed by Wen Qiufang and the findings revealed that the students' critical thinking skill highly influenced their writing achievement, suggesting that cultivating students' critical thinking skill to improve English writing competence is quite necessary.

As to the effects of writing skill on the development of critical thinking, Mehta and Al-Mahrooqi(2015) investigated if it was possible to improve critical thinking skills with the help of in-class practices like group discussions or follow-up writing activities and if so, to what extent. To this end, they benefited from the question format of Norris and Ennis and the rubrics of McLaughlin and Moore to conclude that the students who were engaged with non-stop oral and written activities had a better chance of improving their critical thinking skills as they learnt how to integrate their critical ideas in their academic writing studies in time.Likewise, Rafi (2011) aimed to investigate the effects of critical pedagogy on the development critical thinking through teaching English essay writing. The results of the study showed that incorporating critical thinking in teaching English essay writing promoted reasoning skill among the subjects.

\section{Technology, ELT and writing}

Technology evolves and the ways educators and researchers find to integrate technology into teaching vary. Not a single day has gone by without a new idea on how to combine technology with language teaching since the CALL appeared. Especially, easy and cheap access to the Internet from anywhere started a new era in language teaching. Thus, in this technology and innovation era, many researchers have been interested in the application of 
technological tools and the internet into teaching-learning environments and carried out many studies accordingly.

A group of researchers specifically put emphasis on ELT teachers' perceptions and frequency of technology use in language classes and have investigated it. To begin with, Kazemi and Narafshan (2014) conducted their study to find how the language teachers at a university in Kerman feel about using computer technology in the classroom and what prevents them from using that technology in their classes. The results showed that majority of the professors had positive attitudes and interests in technology use in language classes, yet they had difficulties in integrating technology effectively. They stated two main reasons for this ineffective use of technology. First, the lack of technological tools at the university caused the limited use and second, the teachers could use computers at low-levels which didn't enhance interactive student participation in language learning and teaching process. Similarly, Boersma and Getu (2016) aimed to explore the attitudes of university language teachers in Ethiopia towards the use of Internet in their classes and the reasons that keep them from making use of it effectively. They studied with 21 teachers and found that although they believed in the positive effects of the Internet on student learning, they made use of it at a fairly limited level for their teaching purposes. The reasons behind it were identified as technical problems, unskilled students to use the Internet for language learning, time limits on the syllabi and the teachers' negative perceptions on the work load it brings to the classes. Additionally, a group of researchers wanted to see if ELT teachers were eager to use technologies for their professional development and they did their research to check the teachers' acceptance and readiness in using the cloud-based community as a platform for professional collaboration about their teaching and learning activities(Ishak et al., 2017). They studied with 95 ELT teachers with different teaching backgrounds and found out that given the right training channel, teachers were positive and eager to benefit from and integrate the cloud-based technology in their current teaching practices.

As to the technology and writing relation, it is clear that writing is the skill that challenges students from all levels the most and technology is the notion that attracts the students, who are digital natives, the most. Thus, utilizing technology in writing classes is inevitable. The literature is full of studies that have tried to combine these two for the sake of a better and more fruitful writing instruction. For example, Shafiee et al. (2015) aimed at exploring the effect of teaching pre-writing strategies through different methods of input delivery on EFL learners' writing quantity. They applied three different methods and provided the input in the conventional way, by making use of web and with a mixture of both methods. They studied with 98 students to conclude that the students in the last group for which they used a hybrid method outperformed the learners in the other two groups in terms of the number of the writings they had during the study. Another example focused on the use of social networking sites, especially Facebook, for writing instruction. Tananuraksakul (2014) wanted to see how undergraduate students in Thailand perceive Facebook group usage in a writing class and carried out his study on 53 students. The findings demonstrated that 
Aygün, S. \& Yavuz, F. (2020). The effects of critical thinking instruction through asynchronous learning tools on writing. EduLite: Journal of English Education, Literature, and Culture, 5 (2), 176-191. DOI: http://dx.doi.org/10.30659/e.5.2.176-191

although the students found Facebook a practical, trendy, motivating and beneficial teaching tool, Facebook group could be used as blended learning and learning management system for the students, which meant they could learn with the help of Facebook group studies, but it should not be the only target for them to focus on. Likewise, Vikneswaran and Krish (2016) emphasized online writing habits of students to make them better writers. They took Facebook as a basis for their study, too. In the study, they investigated to identify what motivates ESL students to write in English on Facebook. The students were asked to be active on their Facebook class page by joining the discussions on the page and so finish the writing activities. The data obtained from the students showed that integrating technology into writing tasks helped students become better writers since they utilized each other's feedbacks and opinions that were shared via social networking and performed better thanks to that peer influence on the class web page.Another example study was conducted in Saudi Arabia by a group of researchers (Ezza, Alhuqail, Elhussain, 2019). They studied on struggling student writers of English in Majma'ah University. With this study, the researchers wanted to put emphasis on technology-based instructional intervention in enhancing the composing competence of struggling students. Correspondingly, the data showed that instructional technology could significantly improve students' writing skills. In addition to these, in his study Nabhan (2019) specifically focused on process writing approach and multiliteraciesin writing classes and conducted his study on 28 pre-service teachers. The participants of the study followed the steps of process writing by making use of multiliteracies implemented by the researcher. The findings emphasized that using multiliteracies such as pictures/images, videos in writing activities helped the participants understand the writing materials better.

\section{Blended Learning and ELT}

Online learning emerged as a natural outcome of the CALL based on the Internet boom in the $21^{\text {st }}$ century. Synchronous and asynchronous online learning have appealed to many of the digital natives for learning a new language and consequently, blended learning activities combining synchronous and asynchronous online learning have gained popularity in language teaching. Many researchers attracted by that popularity focused on the teachers' and learners' perceptions and attitudes towards blended learning to reveal details. To begin with, Istifçi (2017) investigated the perceptions of 167 EFL students studying at Anadolu University in Turkey on blended language learning and concluded that although students were fond of blended learning in terms of course format, attendance and flexibility, they preferred face to face communication with the teacher and classmates more. In addition, Sahin-Kız1 (2014) examined 68 EFL students' experiences with blended language learning to find that blended learning environment could create efficient learning according to the students. Similarly, in Saudi Arabia, Ja'ashan (2015) conducted a case study to see the perceptions and attitudes of 130 university students towards blended learning. The findings demonstrated that students had positive attitudes towards blended learning and found it as effective as face to face learning to improve language knowledge and skills. However, it was also concluded that students had some 
negative impressions of it in some aspects such as waste of time, easy chatting and social isolation.

\section{METHOD}

\section{Research design and participants}

This study investigated the effect of online asynchronous critical thinking instruction on students' writing achievements and critical thinking levels. With this purpose, 32 students were categorized into control and experimental groups and asked to open Edmodo accounts for their writing courses. At the beginning of the study, all of the students took CTDS to be assessed on their current attitudes towards critical thinking. During the study, the students in both groups did the same studies in their writing classes in terms of writing achievement. Though they had different instructors, their materials, in-class studies and assignments were the same for 8 weeks. However, the students in the experimental group were provided with some critical thinking activities on Edmodo platform while the control group students got only the provided material without the activities. At the end of the study, the students' writings were assessed on WCVR and CTVR and compared. The data were evaluated by means of SPSS program.

It is an experimental study which consists of a three-phase procedure. First, during the first week of B2 module, Critical Thinking Disposition Scale (CTDS) (Akb1yık, 2002) was given to all the participants (32) to get information about their existing critical thinking attitudes. In addition to this, all the participants were asked to write opinion essays for the portfolio evaluation at the end of the previous module (B1) and these essays were assessed based on Critical Thinking VALUE Rubric (CTVR) (Rhodes, 2009). Next, one of the groups (16) was randomly assigned to an experimental group and the other (16) to control group, and the practice phase got started. Each one of the participants opened a learner account on EDMODO, which is an online learning management system, and two different classes were created for them to register by the researcher. Both groups were exposed to the same writing syllabus with the same book, materials and examples. The researcher was the instructor of the control group and another experienced colleague taught the experimental group during the eight weeks of B2 module. Both instructors taught simultaneously 8 hours of writing each week. However, whereas each of the participants in the experimental group was assigned critical thinking tasks successively on EDMODO, the participants in the control group were provided with the same materials on EDMODO without the tasks that were given to the experiment group. After two weeks of asynchronous critical thinking instruction, all the participants wrote in-class essays on the same topics for their portfolio evaluation in the module assessment. This process was repeated three times for each one of which the experimental group was assigned different critical thinking tasks based on Numrich's sequence of critical thinking tasks. Finally, writing achievements in three different types of essays written by experimental group and control group were assessed by two-raters, the instructors of each class, for reliability based on Written Communication VALUE Rubric (WCVR) (Rhodes, 2009) and compared. Besides, the third essays, which were argumentative essays, were assessed one more time but 
Aygün, S. \& Yavuz, F. (2020). The effects of critical thinking instruction through asynchronous learning tools on writing. EduLite: Journal of English Education, Literature, and Culture, 5 (2), 176-191. DOI: http://dx.doi.org/10.30659/e.5.2.176-191

based on Critical Thinking VALUE Rubric so that the results could be compared to the results of the learners' opinion essays in terms of critical thinking. During the last week of the module, all the participants were given Critical Thinking Disposition Scale (Akb1y1k, 2002) as the post-test.

The population of the study included 32 B2 level Turkish learners of English at Yalova University School of Foreign Languages. The native languages of all the participants are Turkish and they were all placed in A2 level (Common European Framework of Reference) classes after they took the placement test which was administered by School of Foreign Languages at the beginning of 2017-2018 academic year fall term. The students who were successful enough to meet the requirements of A2 and B1 levels of English according to the CEFR started B2 module at the beginning of the spring term, so they were considered to have more or less the same level of English proficiency. During the previous modules, they all had the same courses, which were Academic Reading, Listening, Writing and Grammar, and took the same exams to be able to pass a module. They were also required to write 4 pieces of writing on the given topics in limited time for their portfolio assessments in each module as a part of the module evaluation criterion.

\section{Tools}

Only quantitative data were collected for the current study. Critical Thinking Disposition Scale by Akbiyık (2002) was administered as pre-test and post-test to find out the participants' current critical thinking attitudes and if a difference appeared in the critical thinking attitudes of the experimental group after the critical thinking treatment. All the participants' writing achievements were assessed based on the Written Communication VALUE Rubric (WCVR) developed by Association of American Colleges and Universities (2009). The three different types of essays, which were Cause / Effect Essay, Compare / Contrast Essay and Argumentative Essay, were evaluated by the two raters after the students wrote on the given topics in one hour without being informed about the time of the writing hour. The students were required to write each essay after they had been instructed about the genre, organization and related vocabulary on the essay type and had done some classroom practice meanwhile. Finally, the students' argumentative essays and opinion essays, which they had written at the end of B1 module, were assessed based on Critical Thinking VALUE Rubric to be compared.

To observe the students' attitudes towards asynchronous learning tools, all the participants were introduced to Edmodo, an online learning management system, and asked to open an account on it and register to the classes that had been created by the instructors. All the related data for the writing tasks were provided to both groups via Edmodo. While the experimental group students' answers to the tasks were evaluated, control group students were just asked to read and 'like' the provided material so that their participation could be observed and analyzed. 


\section{Statistical procedure}

The data gathered were analyzed by using IBM SPSS V23 and the normality of the dataset was checked through Shapiro-Wilk test. Since the results revealed that the dataset was normally distributed, parametric tests were used to analyze the data. First, to distinguish the critical thinking attitudes of all the participants, descriptive statistics were calculated on the pre-test of CTDS $(a=87)$. Next, two experienced EFL teachers graded the writing performances of all the students for 3 different essay types (cause/effect, compare/contrast, argumentative) in accordance with WCVR. For inter-rater reliability, correlation coefficients for all the scores of the raters were calculated and the data showed that inter-rater reliability was obtained. Then, the average scores of both raters for each writing performance test were calculated and mean scores, standard deviation, minimum and maximum values of them found. Additionally, the opinion essays (pre-test) and argumentative essays (post-test) of all the participants were scored by the two raters based on CTVR and the average scores for all the subcategories and overall were calculated. After that, in terms of pre- and post-tests, mean scores, standard deviations, minimum and maximum scores, standard error of means in terms of explanation of issues, evidence, the influence of assumptions, students position, conclusions and total score were calculated. Finally, pre- and post-test results of CTDS for the experimental group were compared.

\section{RESULTS AND DISCUSSION}

The results regarding the critical thinking attitudes of the students are based on the CTDS (Akbiy1k, 2002) and the descriptive statistics on the students' answers at the beginning of the study showed that the students in both groups have a moderate level of critical thinking dispositions, as shown in Table 1.

Table 1. Descriptive Statistics of Groups in Terms of Critical Thinking Dispositions

\begin{tabular}{lclll}
\hline \multirow{2}{*}{ Descriptive Statistics } & \multicolumn{2}{c}{ Groups } & & Test statistics $\quad P \quad$ Control \\
& Experimental & 111.50 & \\
\cline { 2 - 3 } Mean & 11.25 & 6.26 & $\mathrm{t}=0.1010 .921$ \\
Standard Deviation & 7.72 & 100 & \\
Minimum & 100 & 125 & $-4.823: 5.323$ \\
Maximum & 125 & & \\
95\% Confidence Interval of the Difference & & \\
\hline
\end{tabular}

To see the students' attitudes towards asynchronous learning tools, the students in both groups were asked to open accounts on Edmodo and register the class that had been created for them so that they could follow the materials or tasks provided by the researcher on that platform. By asynchronous learning tool, Edmodo online platform was taken into consideration and students' visits on Edmodo were observed to see their attitudes towards using asynchronous learning tools for writing classes. For 
Aygün, S. \& Yavuz, F. (2020). The effects of critical thinking instruction through asynchronous learning tools on writing. EduLite: Journal of English Education, Literature, and Culture, 5 (2), 176-191. DOI: http://dx.doi.org/10.30659/e.5.2.176-191

this purpose, the number of the tasks that had been completed by the students in the experimental group was counted. The results are shown in Figure 1.

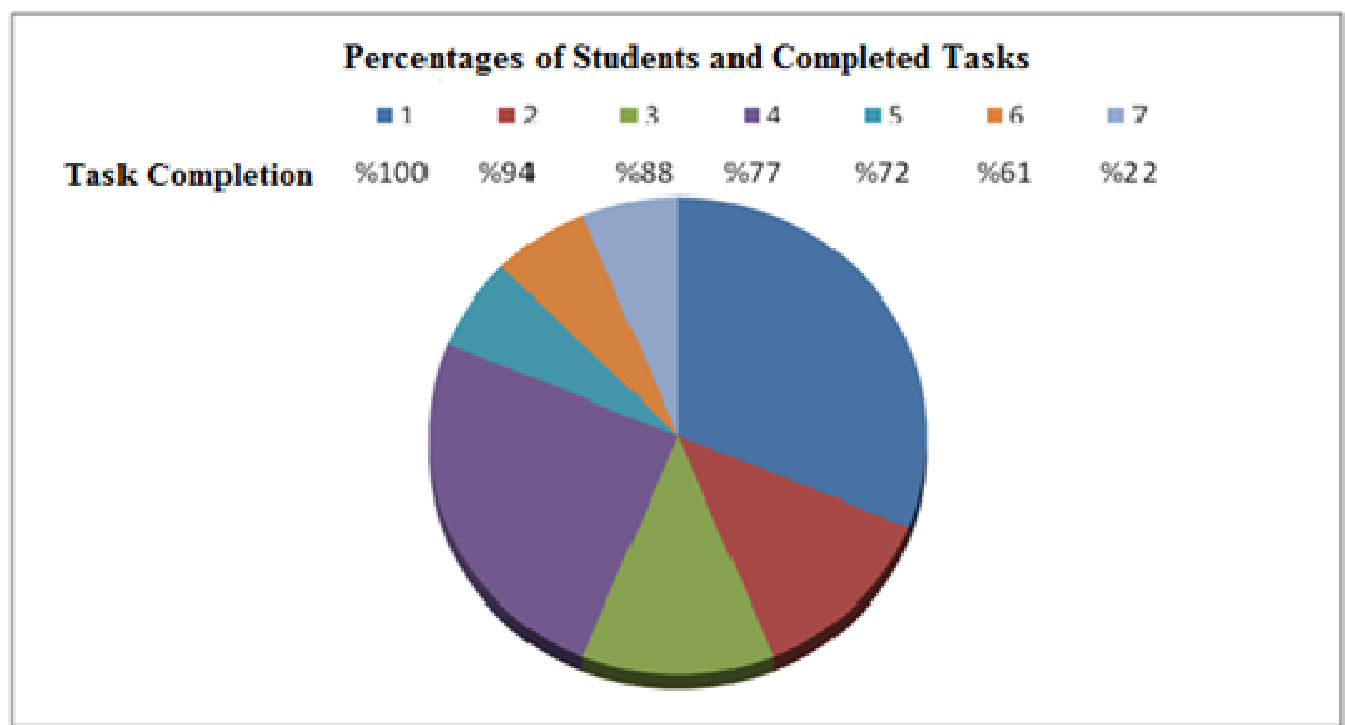

Figure 1: Percentages of Students and Completed Tasks in the Experimental Group

These results show that 5 students (31.25\%) out of 16 in the experimental group completed $100 \%$ of all the tasks (18) on Edmodo. 2 students (12.5\%) completed 17 tasks in total (94\%) and 2 students $(12.5 \%)$ did 16 tasks (88\%). 4 students (25\%) did 14 tasks (77\%). Finally, 1 student completed 13 tasks (72\%), and 1 student completed 11 tasks (61\%). While most of the tasks were completed on Edmodo by most of the students in total ( $81 \%$ of the students did more than $75 \%$ of the tasks at least), just 1 student was unwilling to use Edmodo and do the tasks. That student completed only 2 tasks out of $18(22 \%)$.

The students in the control group weren't assigned anything specific on Edmodo, yet they got some materials to read or watch for their writing classes; therefore, they were asked to check their accounts regularly and follow the provided materials by clicking on the 'like' button after they study the material. To see the student participation, student visits on Edmodo and 'likes' were considered. All the students in the control group were provided with 9 different materials in total during the study. The results show that $1^{\text {st }}$ material was studied by 11 students, $2^{\text {nd }}$ by $10,3^{\text {rd }}$ by 13 , $4^{\text {th }}$ by $10,5^{\text {th }}$ by 9 , $6^{\text {th }}$ by 11 , $7^{\text {th }}$ by $6,8^{\text {th }}$ by 10 and 9 th by 5.1 student did not participate at all. If all the students had responded to all the materials, the total number of times that were studied on Edmodo would be 144. However, when student participation was considered in total, it was calculated that all the materials were studied 59 times by the students in the control group. 


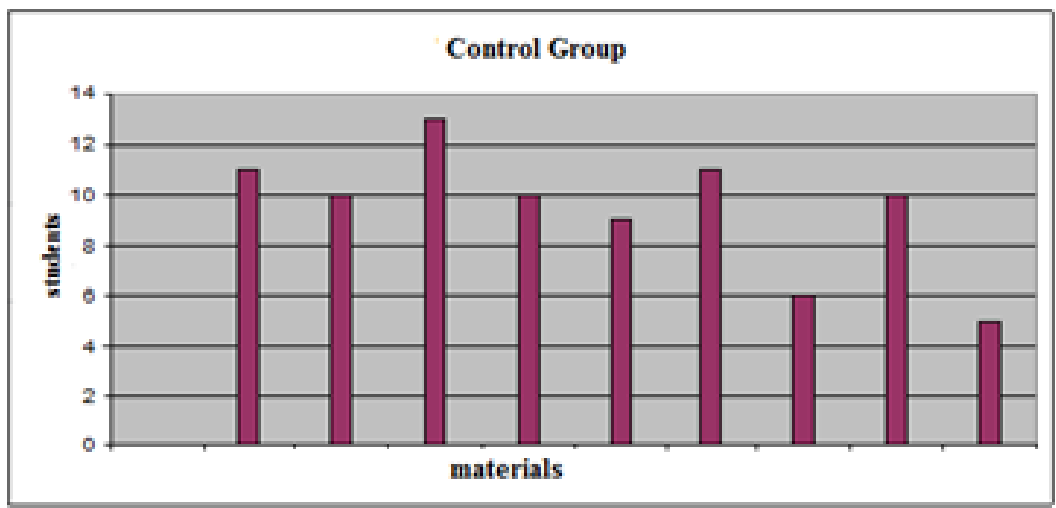

Figure 2: Task Completions of Control Group Students

Based on the findings of students' use of Edmodo for their writing classes, it appears that students do not feel motivated enough to use asynchronous learning tools unless they are specifically assigned to do something on them. The students in the control group were unwilling to check their Edmodo accounts and follow the provided materials during the study. Although almost all of them downloaded the Edmodo App on their smartphones and were frequently urged to check their accounts by the teacher, nearly half of the materials were only studied on. It shows that though students spend much time online and like to do so, they avoid spending time on asynchronous learning tools and making use of them by themselves when they are not asked to engage in some activities for the provided materials. On the other hand, the students in the control group, who were assigned some tasks on the provided materials, used Edmodo much more frequently and willingly. It was observed that they insistently asked for feedback on their assignments on Edmodo and sent messages to the teacher about the tasks sometimes.

To find the effects of engaging in critical thinking activities on the student use of critical thinking skill in the writing tasks, students' opinion essays were evaluated as the pre-test of critical thinking assessment and they were graded in terms of explanation of issues, evidence, the influence of assumptions, student position and conclusion by the two EFL teachers, each of whom was the writing instructor of each group. The results of both groups were analyzed and they show that there are no significant differences between the pre-test scores for the control and experimental group in terms of critical thinking, as shown in Table 2. These findings indicate that both groups were equally unsuccessful at critical thinking while writing at the beginning of the study as their total critical thinking scores for the opinion essays were more or less the same and respectively low. What's more, as regards to the findings of the descriptive statistics of students' critical thinking attitudes, it is clear that students in both groups are not inclined to think critically. To know how to think critically is what is expected from university students in this era, but when the students' attitudes towards critical thinking are assessed, it appears that students do not have tendencies to do so; accordingly, they cannot apply 
Aygün, S. \& Yavuz, F. (2020). The effects of critical thinking instruction through asynchronous learning tools on writing. EduLite: Journal of English Education, Literature, and Culture, 5 (2), 176-191. DOI: http://dx.doi.org/10.30659/e.5.2.176-191

critical thinking skills which they are mostly unaware of in their writing courses.

Table 2. Independent Samples Test for Opinion Essays of Control and Experimental Groups

\begin{tabular}{|c|c|c|c|c|c|c|c|c|}
\hline \multirow[t]{2}{*}{ Items } & \multirow{2}{*}{ Group } & \multirow{2}{*}{$\begin{array}{c}\text { Mea } \\
\mathrm{n}\end{array}$} & \multirow{2}{*}{$\begin{array}{c}\text { Std. } \\
\text { Deviatio } \\
\mathrm{n}\end{array}$} & \multirow{2}{*}{$\begin{array}{l}\text { Std. } \\
\text { Error } \\
\text { Mea } \\
\mathrm{n}\end{array}$} & \multicolumn{2}{|c|}{$\begin{array}{c}95 \% \\
\text { Confidence } \\
\text { Interval of } \\
\text { the } \\
\text { Difference }\end{array}$} & \multirow{2}{*}{$\begin{array}{c}\text { Test } \\
\text { statistic } \\
\mathrm{s}\end{array}$} & \multirow[t]{2}{*}{$\mathrm{P}$} \\
\hline & & & & & lower & uppe & & \\
\hline \multirow{2}{*}{$\begin{array}{c}\text { Explanation } \\
\text { of issues }\end{array}$} & Control & 2.19 & .85 & .213 & \multirow[b]{2}{*}{-.66} & \multirow[b]{2}{*}{.472} & \multirow[b]{2}{*}{-.338} & \multirow[b]{2}{*}{$\begin{array}{c}.73 \\
7\end{array}$} \\
\hline & $\begin{array}{c}\text { Experimenta } \\
1\end{array}$ & 2.28 & .71 & .177 & & & & \\
\hline \multirow[t]{2}{*}{ Evidence } & Control & 1.38 & .89 & .221 & \multirow{2}{*}{.704} & \multirow[b]{2}{*}{.579} & \multirow[b]{2}{*}{.199} & \multirow[b]{2}{*}{$\begin{array}{c}.84 \\
4 \\
\end{array}$} \\
\hline & $\begin{array}{c}\text { Experimenta } \\
1\end{array}$ & 1.44 & .89 & .223 & & & & \\
\hline \multirow{2}{*}{$\begin{array}{l}\text { Influence of } \\
\text { assumptions }\end{array}$} & Control & 1.19 & .54 & .136 & \multirow{2}{*}{$\begin{array}{c}- \\
.757\end{array}$} & \multirow[b]{2}{*}{.007} & \multirow[b]{2}{*}{-2.007} & \multirow[b]{2}{*}{$\begin{array}{c}.05 \\
4\end{array}$} \\
\hline & $\begin{array}{c}\text { Experimenta } \\
1 \\
\end{array}$ & 1.56 & .51 & .128 & & & & \\
\hline \multirow{2}{*}{$\begin{array}{l}\text { Student } \\
\text { position }\end{array}$} & Control & 2.47 & .83 & .207 & \multirow{2}{*}{$\begin{array}{c}- \\
.582\end{array}$} & \multirow[b]{2}{*}{.645} & \multirow[b]{2}{*}{.104} & \multirow[b]{2}{*}{$\begin{array}{l}.91 \\
8 \\
\end{array}$} \\
\hline & $\begin{array}{c}\text { Experimenta } \\
1\end{array}$ & 2.44 & .87 & .218 & & & & \\
\hline \multirow{2}{*}{$\begin{array}{c}\text { Conclusion/ } \\
\text { consequence } \\
\mathrm{s}\end{array}$} & Control & 1.81 & .66 & .164 & \multirow{2}{*}{.815} & \multirow[b]{2}{*}{.128} & \multirow[b]{2}{*}{-1.489} & \\
\hline & $\begin{array}{c}\text { Experimenta } \\
1 \\
\end{array}$ & 2.16 & .65 & .163 & & & & $\begin{array}{c}.14 \\
7 \\
\end{array}$ \\
\hline \multirow[t]{2}{*}{ Total } & Control & 9.03 & 3.16 & .791 & \multirow{2}{*}{$\begin{array}{c}- \\
2.92 \\
8\end{array}$} & \multirow[b]{2}{*}{1.241} & \multirow[b]{2}{*}{-.827} & \\
\hline & $\begin{array}{c}\text { Experimenta } \\
1\end{array}$ & 9.88 & 2.58 & .645 & & & & $\begin{array}{c}.41 \\
5\end{array}$ \\
\hline
\end{tabular}

Students' argumentative essays were the post-tests for critical thinking assessment and they were evaluated on the same criteria. The analyses of the results show that there is a significant difference between the post-test scores for the control and experimental group. The post-test results of both groups are shown in Table 3.

Table 3. Independent Samples Test for Argumentative Essays of Control and Experimental Groups

\begin{tabular}{|c|c|c|c|c|c|c|c|c|}
\hline \multirow{2}{*}{ Items } & \multirow[b]{2}{*}{ Group } & \multirow[b]{2}{*}{ Mean } & \multirow{2}{*}{$\begin{array}{c}\text { Std. } \\
\text { Deviation }\end{array}$} & \multirow{2}{*}{$\begin{array}{l}\text { Std. } \\
\text { Error } \\
\text { Mean }\end{array}$} & $\begin{array}{r}9 \\
\text { Con } \\
\text { Interv } \\
\text { Diff }\end{array}$ & $\begin{array}{l}\% \\
\text { lence } \\
\text { of the } \\
\text { ence }\end{array}$ & \multirow{2}{*}{$\begin{array}{c}\text { Test } \\
\text { statistics }\end{array}$} & \multirow{2}{*}{$\mathrm{p}$} \\
\hline & & & & & lower & upper & & \\
\hline Explanation & Control & 1.94 & 1.06 & .266 & -1 & & & \\
\hline
\end{tabular}




\begin{tabular}{|c|c|c|c|c|c|c|c|c|}
\hline of issues & Experimental & 2.56 & 1 & .249 & .369 & .119 & -1.715 & .097 \\
\hline \multirow[t]{2}{*}{ Evidence } & Control & 1.5 & .73 & .183 & \multirow{2}{*}{1.294} & \multirow[b]{2}{*}{.044} & \multirow[b]{2}{*}{-1.908} & \multirow[b]{2}{*}{.066} \\
\hline & Experimental & 2.13 & 1.09 & .272 & & & & \\
\hline \multirow{2}{*}{$\begin{array}{l}\text { Influence of } \\
\text { assumptions }\end{array}$} & Control & 1.81 & .98 & .245 & \multirow{2}{*}{$\begin{array}{c}- \\
1.595\end{array}$} & \multirow[b]{2}{*}{.405} & \multirow[b]{2}{*}{-3.432} & \multirow[b]{2}{*}{.002} \\
\hline & Experimental & 2.81 & .63 & .157 & & & & \\
\hline \multirow{2}{*}{$\begin{array}{l}\text { Student } \\
\text { position }\end{array}$} & Control & 2.03 & .92 & .230 & \multirow{2}{*}{$\begin{array}{c}- \\
1.239\end{array}$} & \multirow[b]{2}{*}{.052} & \multirow[b]{2}{*}{-1.878} & \multirow[b]{2}{*}{.070} \\
\hline & Experimental & 2.63 & .87 & .217 & & & & \\
\hline \multirow{2}{*}{$\begin{array}{l}\text { Conclusion/ } \\
\text { consequences }\end{array}$} & Control & 1.88 & .74 & .185 & \multirow{2}{*}{$\begin{array}{c}- \\
1.381\end{array}$} & \multirow[b]{2}{*}{-.369} & \multirow[b]{2}{*}{-3.530} & \multirow[b]{2}{*}{.001} \\
\hline & Experimental & 2.75 & .66 & .165 & & & & \\
\hline \multirow[t]{2}{*}{ Total } & Control & 9.16 & 3.93 & .982 & \multirow{2}{*}{6.446} & \multirow[b]{2}{*}{-.929} & \multirow[b]{2}{*}{-2.730} & \multirow[b]{2}{*}{.010} \\
\hline & Experimental & 12.84 & 3.71 & .927 & & & & \\
\hline
\end{tabular}

When the results of each group before and after the intervention are compared, it is clearly seen that the results of the experimental group students' argumentative essays are much higher than their opinion essay results in terms of critical thinking. On the other hand, no statistical difference can be observed between pre- and post-test scores of the control group. These findings revealed that experimental group students' use of critical thinking skills in their writings was positively affected. It is apparently seenthat critical thinking activities alongside writing studies develop students' critical thinking ability in some ways; accordingly, students can implement those skills while writing and present their ideas more critically. Regarding the findings, it is clear that students who participate in critical thinking activities are a lot better, specifically, in terms of evaluating assumptions on a topic and making conclusions. Thanks to some critical thinking tasks, they can think more critically and express and support their ideas in a better way while writing. As a result, supporting writing classes with critical thinking studies contributes to the students' abilities to use high order thinking skills and implementation of them in their writings.

"How does engaging in critical thinking activities via asynchronous learning tools affect students' writing achievements?" is the final research question and to answer it, the students in both groups were required to write three different types of essays in time. First, the students in both groups wrote cause/effect essays for their portfolio evaluation and their results were assessed based on WCVR. The results show that experimental group students' writing achievements for cause/effect essay are higher than the control group students'; the difference between the scores is significant $(p=0.001)$. The mean score for the control group is 11.66 and the mean score for the experimental group is 14.38. When the students' writing performances on Compare/Contrast essays were analyzed in accordance with WCVR, the results show that there is not a significant difference between the control group and experimental group scores $(p=0.102)$. The mean score for the control group is 11.80 and the mean score for the experimental group is 13.38. Students' last performances were evaluated on their argumentative essays and the results were similar with the results of Compare/Contrast writing performance. There are no significant differences between the writing achievements of the control group students and experimental group students $(p=0.085)$. The mean score for the control group is 11.41 and the mean score 
Aygün, S. \& Yavuz, F. (2020). The effects of critical thinking instruction through asynchronous learning tools on writing. EduLite: Journal of English Education, Literature, and Culture, 5 (2), 176-191. DOI: http://dx.doi.org/10.30659/e.5.2.176-191

for the experimental group is 13.88. Based on these findings, it can be said that engaging in online critical thinking activities does not contribute to the writing achievements of the students. The writing achievements of the students in experimental and control group did not differ significantly in compare/contrast and argumentative essay writing. However, the results of experimental group cause/effect essays are higher than of control group essays. One possible reason for that is the choice of topic. Since 'immigration' is not something students know and think a lot about, making them think about it deeply and critically helped them write better on that topic. Consequently, it can be stated that combining writing classes with critical thinking activities affects students' writing achievements on academic topics.

\section{CONCLUSION}

This study was carried out to reveal some datum on how effective critical thinking instruction through asynchronous learning tools was on students' writing performance. Given that the importance of asynchronous learning and its influence on student progress with regard to writing achievement and critical thinking development is not revealed, the study aimedto look over B2 level Turkish EFL students' current use of critical thinking skills in writing courses and to study B2 level Turkish EFL students' critical thinking progress in writing performance through asynchronous learning tools. In addition, this study intended to reveal B2 level Turkish EFL students' asynchronous learning habits in writing courses and to compare B2 level Turkish EFL students' progress in traditional writing courses supported by asynchronous learning tools to the student progress under the treatment of critical thinking through asynchronous learning tools. After an eight-week treatment on the experimental group students, the study concluded that the writingperformancesof the experimental group students did not improve notably despitethe critical thinking treatment. Though, they increased the use of critical thinking skills while writing. On the other hand, neither the writing performances of the control group students nor their use of critical thinking skills changed during the study. Finally, the study showed that exposing experimental group students to critical thinking activities for some time even repeatedly didn't mean much. Even if critical thinking implementation in writing got better after some critical thinking instruction, students' attitudes, in general, remained the same. Though their abilities to evaluate assumptions and make conclusions were enhanced while writing on a topic, they were still not good critical thinkers and needed much more practice to reach the level of 'capstone'.

\section{REFERENCES}

Akbıyık, C., \& Seeroğlu,S. S. (2002). Eleştirel Düşünme Eğilimleri veAkademik Başarı, "yayınlanmamış yükseklisans tezi". HacettepeÜniversitesi Sosyal Bilimler Enstitüsü, Ankara. 
Boersma, E., \& Getu, T. (2016). Ethiopian EFL Teachers' Perceptions and Utilization of Mediational Potentials of the Internet in ELT. Teaching English with Technology, 16(1), 26-40.

Dong, T., \& Yue, L. (2015). A Study on Critical Thinking Assessment System of College English Writing. English Language Teaching, 8(11), 176-182.

Ezza, E. S. Y., Alhuqail, E. A., \&Elhussain, S. W. (2019). Technology-based instructional intervention into an EFL writing classroom. Cypriot Journal of Educational Sciences, 14(4), 507-519.

Facione, P. (1990). The Delphi Report: Critical Thinking: A Statement Of Expert Consensus For Purposes Of Educational Assessment And Instruction. Millbrae California; California Academic Press.

Golpour, F. (2014). Critical Thinking and EFL Learners' Performance on Different Writing Modes. Journal of Pan-Pacific Association of Applied Linguistics, 18(1).

Huber, C. R., \&Kuncel, N. R. (2016). Does college teach critical thinking? A meta-analysis. Review of Educational Research, 86(2), 431-468.

Ishak, M. F. F., Rahamat, R., Fadzilah, M. H. H., \& Abu, A. G. (2017). G+ Community: Measuring teachers' readiness and acceptance. Edulite: Journal of English Education, Literature and Culture, 2(2), 361-376.

Istifci, I. (2017). Perceptions of Turkish EFL Students on Online Language Learning Platforms and Blended Language Learning. Journal of Education and Learning, 6(1), 113-121.

Ja'ashan, M. M. N. H. (2015). Perceptions and attitudes towards blended learning for English courses: A case study of students at University of Bisha. English Language Teaching, 8(9), 40.

Jabr, D. (2003). Teaching critical thinking in the English language classroom : the case of Palestine. Mediterranean Journal of Educational Studies, 8(2), $137-162$

Jensen Jr, R. D. (2015). The Effectiveness of the Socratic Method in Developing Critical Thinking Skills in English Language Learners. Online Submission

Kazemi, A., \&Narafshan, M. H. (2014). Technology and English Language Teaching (ELT). Advances in Language and Literary Studies, 5(6), 60-67.

Marin, M. A., \& de la Pava, L. (2017). Conceptions of Critical Thinking from University EFL Teachers. English Language Teaching, 10(7), 78.

Mehta, S. R., \& Al-Mahrooqi, R. (2015). Can thinking be taught? Linking critical thinking and writing in an EFL context. RELC Journal, 46(1), 2336.

Moore, T. (2013). Critical thinking: Seven definitions in search of a concept. Studies in Higher Education, 38(4), 506-522.

Nabhan, S. (2019). Bringing multiliteracies into process writing approach in ELT classroom: Implementation and reflection. EduLite: Journal of English Education, Literature and Culture, 4(2), 156-170.

Plotnikova, N. F., \&Strukov, E. N. (2019). Integration of teamwork and critical thinking skills in the process of teaching students. Cypriot Journal of Educational Sciences, 14(1), 1-10. 
Aygün, S. \& Yavuz, F. (2020). The effects of critical thinking instruction through asynchronous learning tools on writing. EduLite: Journal of English Education, Literature, and Culture, 5 (2), 176-191. DOI: http://dx.doi.org/10.30659/e.5.2.176-191

Rafi, M. S. (2011). Promoting critical pedagogy in language education. International Research Journal of Arts and Humanities, 39(39), 105.

Rhodes, T. (2009). Assessing outcomes and improving achievement: Tips and tools for using the rubrics. Association of American Colleges and Universities.

Sahin-Kizil, A. (2014). Blended instruction for EFL learners: Engagement, learning and course satisfaction. JALT CALL Journal, 1O(3), 175-188.

Shafiee, S., Koosha, M., \&Afghari, A. (2015). CALL, prewriting strategies, and EFL writing quantity. English Language Teaching, 8(2), 170.

Shaila, M. Y., \& Trudell, B. (2010). From Passive Learners to Critical Thinkers: Preparing EFL Students for University Success. In English Teaching Forum (Vol. 48, No. 3, pp. 2-9). US Department of State. Bureau of Educational and Cultural Affairs, Office of English Language Programs, SA-5, 2200 C Street NW 4th Floor, Washington, DC 20037.

Tananuraksakul, N. (2014). Use of Facebook group as blended learning and learning management system in writing. Teaching English with Technology, 14(3), 3-15.

Vikneswaran, T., \&Krish, P. (2016). Utilising social networking sites to improve writing: a case study with Chinese students in Malaysia. Technology, Pedagogy and Education, 25(3), 287-300.

*Note: This study has been designed from the author's master's thesis in 2018. 